\title{
THE IMPLEMENTATION OF PHARMACEUTICAL SERVICE STANDARD POLICY FOR ACCREDITATION OF THE COMMUNITY HEALTH CENTER IN BEKASI, WEST JAVA
}

\author{
Wahyu Eka Arini' ${ }^{1}$, Dumilah Ayuningtyas² \\ ${ }^{1)}$ Masters Program in Public Health, Universitas Indonesia \\ ${ }^{2)}$ Health Policy and Administration Department, Faculty of Public Health, \\ Universitas Indonesia
}

\begin{abstract}
Background: The pharmaceutical practice varies in different countries and continents, including developing countries, transitional and developed countries. Pharmaceutical policy, as part of national health care policy, is concerned with the provision and use of medicines. Pharmacists are critical to the medicines management process, yet are often largely detached from policy development. This study aimed to determine the implementation of pharmaceutical service standard policy for accreditation of the community health center (Puskesmas) in Bekasi, West Java.

Subjects and Method: This was a cross-sectional study conducted at several community health centers (Puskesmas) in Bekasi, in August 2018. The main informants for this study were technical pharmacists. The triangulation informants were obtained from the Bekasi Health Office and the Ministry of Health. The variables under study were communication, resource, disposition, birocration structure, support, and inhibiting factors. The data were collected by in-depth interview and observation. The data were analyzed descriptively.

Results: The Minister of Health Regulation Number 74 of 2016 concerning Pharmaceutical Service Standards had been implemented in all of the studied Puskesmas. Policy communication had worked well. Resources in one setting were adequate, but in another were inadequate. The policy had been well implemented by the Puskesmas. The bureaucratic structure had produced and impelemnted the standard operational procedure (SOP). The supporting factors included commitment from all parties related to this policy. The inhibiting factors included inconsistent implementation of the pharmaceutical SOP after the accreditation.
\end{abstract}

Conclusion: The pharmaceutical service policy and standard have been well implemented in the community health center.

Keywords: pharmaceutical service, standard policy, accreditation

\section{Correspondence:}

Wahyu Eka Arini. Masters of Public Health, Faculty of Public Health, Universitas Indonesia. Email: ariniwahyuo1@gmail.com Mobile: 081319362688.

\section{BACKGROUND}

The Health Law Number 36 of 2009 has mandated that the government is responsible for the availability of all forms of quality, safe, efficient and affordable health efforts (Kemenkumham, 2009). Health efforts carried out include improving services to health
}

facilities including basic health care facilities through improving health center services. Health center is a basic health service facility that organizes public health efforts and first-rate individual health efforts, by prioritizing promotive and preventive efforts, to achieve the highest degree of public 
health in its working area (Ministry of Health, 2014).

The era of national health insurance, health center spearheaded health services for the community. To be able to collaborate with the Social Security Guarantee Agency, first-level health facilities must have been accredited (Ministry of Health, 2013). This is in line with the Minister of Health Regulation Number 75 of 2014 concerning health center which states that health center must be accredited periodically at least 3 (three) years (Ministry of Health, 2014). In the 2015-2018 Regional Medium Term Development Plan (RPJMN) the government has targeted 5600 Puskesmas accredited in 2019 (Bappenas, 2014). Health center accreditation aims to strengthen public trust in health care facilities and evaluation materials in improving health services to the community (Ministry of Health, 2015a). As well as support with research that states that the implementation of accreditation in the field of public health can change performance for the better (Riley et al., 2015).

Pharmacy services at the Community Health Center are an integral part of the implementation of health efforts that play an important role in improving the quality of health services for the community (Ministry of Health, 2016). Pharmacy services are integrated activities with the aim of identifying, preventing and resolving drug problems and health-related problems whose paradigm has shifted from product orientation to being patient-oriented to the philosophy of pharmaceutical services. In the Ministry of Health's strategic plan, it has set an indicator target that $50 \%$ of Puskesmas in Indonesia have implemented pharmaceutical service standards that are in accordance with the prevailing laws and regulations in 2019 (Ministry of Health, 2015b). In line with these objectives, there is one point in the health center accreditation instrument is drug service.

The results of the performance report of the Directorate General of Pharmaceuticals and Medical Devices in 2017 stated that in 2017 out of 9754 health center units in Indonesia, only 50.01\% had met pharmaceutical service standards exceeding the target set in the Ministry of Health's Strategic Plan of $50 \%$ (Pharmaceutical Services Directorate, 2018 ).

Pharmacy services, as one indicator that will be assessed in the assessment of accreditation plays an important role. The implementation of existing pharmaceutical service standard policies can be used as an instrument to achieve good results in accreditation assessments. According to Edward III in Anggara (2018), there are four variables that influence the success or failure of a policy implementation, namely communication, resources, disposition or attitude, and bureaucratic structure (Anggara, 2014).

The Bekasi City Health Office has implemented a standard pharmacy service policy at the puskesmas in order to improve services and the process of achieving accreditation. The results of the Ministry of Health's accreditation team assessment of 36 health center units in Bekasi city were only 9 health centers that have been accredited and there are some that 
will be accredited in 2018. A study in 2018 showed that Pharmacy services at the Bekasi City Health Center have counseled and provided drug information, but have not fully complied with pharmaceutical service standards at the puskesmas and are in the moderate category (Grahmidri, 2018).

This study aims to describe and analyze qualitatively the application of the Minister of Health Regulation No. 74 of 2016 concerning Pharmaceutical Service Standards at the health center in the context of accreditation of health center in Bekasi in terms of the theory of policy analysis Edward III, namely communication, source power disposition, and bureaucratic structure.

\section{SUBJECTS AND METHOD \\ 1. Study Design}

This was a qualitative study conducted at several places including community health center (Puskesmas) in Bekasi, health office Bekasi, and ministry of health in August 2018.

2. Study Informants

Several informants were selected for this study included: the Head of SubDirectorate of Quality and Accreditation of the Directorate of Primary Health Services, Head of Pharmaceutical Management Section of Pharmaceutical Management and Clinical Sub-Directorate of Pharmaceutical Services, Head of Pharmaceutical Section of Bekasi City Health Office, Pharmacy staff at accredited Puskesmas Pharmacy Units, Pharmacists in Unit Pharmacy Puskesmas in Bekasi City that has not been accredited.

\section{Data Analysis}

The data were collected by in-depth interview and observation. The data were analyzed descriptively.

\section{RESULTS \\ 1. Informants Characteristics \\ The characteristic of the informants who participated in the research des- cribed in Table 1 based on education, age, gender, length of work, and position.}

Table 1. Informant Characteristics

\begin{tabular}{|c|c|c|c|c|c|}
\hline Informant & $\begin{array}{l}\text { Educational } \\
\text { background }\end{array}$ & $\begin{array}{c}\text { Age } \\
\text { (years) }\end{array}$ & Gender & $\begin{array}{l}\text { Working } \\
\text { period } \\
\text { (years) }\end{array}$ & Position \\
\hline Inf A & $\begin{array}{l}\text { Pharmacy } \\
\text { Vocational } \\
\text { School }\end{array}$ & 20 & Female & 2 & $\begin{array}{l}\text { Pharmacy Staff } \\
\text { of the } \\
\text { accredited } \\
\text { health center }\end{array}$ \\
\hline $\operatorname{Inf} B$ & $\begin{array}{l}\text { D3 of } \\
\text { Pharmacy }\end{array}$ & 51 & Female & 28 & $\begin{array}{l}\text { Pharmacy Staff } \\
\text { of the } \\
\text { accredited } \\
\text { health center }\end{array}$ \\
\hline $\operatorname{Inf} C$ & $\begin{array}{l}\text { Under graduare } \\
\text { program of } \\
\text { Pharmacist }\end{array}$ & 41 & Female & 12 & $\begin{array}{l}\text { Pharmaceutical } \\
\text { Health Center } \\
\text { Staff Has Not / } \\
\text { Will Be } \\
\text { Accredited }\end{array}$ \\
\hline
\end{tabular}




\begin{tabular}{|c|c|c|c|c|c|}
\hline Inf D & $\begin{array}{l}\text { Under graduare } \\
\text { program of } \\
\text { Pharmacist }\end{array}$ & 30 & Female & 7 & $\begin{array}{l}\text { Pharmaceutical } \\
\text { Health Center } \\
\text { Staff Has Not / } \\
\text { Will Be }\end{array}$ \\
\hline $\begin{array}{l}\text { Triangulation } \\
\text { of Informant } \\
\text { E }\end{array}$ & $\begin{array}{l}\text { Under graduare } \\
\text { program of } \\
\text { Pharmacist }\end{array}$ & 37 & Male & 12 & $\begin{array}{l}\text { Accredited } \\
\text { Head of } \\
\text { Pharmacy } \\
\text { Management } \\
\text { Section }\end{array}$ \\
\hline $\begin{array}{l}\text { Triangulation } \\
\text { of Informant } \\
\text { F }\end{array}$ & $\begin{array}{l}\text { Master's } \\
\text { program }\end{array}$ & 54 & Male & 22 & $\begin{array}{l}\text { Head of Sub } \\
\text { Directorate. } \\
\text { Quality and } \\
\text { Accreditation }\end{array}$ \\
\hline $\begin{array}{l}\text { Triangulation } \\
\text { of Informant } \\
\text { G }\end{array}$ & $\begin{array}{l}\text { Under graduare } \\
\text { program of } \\
\text { Pharmacist }\end{array}$ & 42 & Female & 13 & $\begin{array}{l}\text { Head of } \\
\text { Pharmacy } \\
\text { Section of } \\
\text { Bekasi City } \\
\text { Health Office }\end{array}$ \\
\hline
\end{tabular}

Source: Primary Data

\section{Communication}

The first aspect seen in this study is the aspect of communication. Communication related to how the policy communicated to the organization (Ayuningtyas, 2018).

Communication also depends on how the policy is in the process of transmission, clarity, and consistency (Anggara, 2014).

\section{a. Transmission}

A good transmission process in a policy will impact that the policy is implemented properly. Some informants received socialization or the results of the dissemination of policy information in the implementation of this policy came from the Head of the Community Health Center, the City Health Office Pharmacy Section, or initiatives to search for themselves through media such as the internet.

In the triangulation informants, the policy makers also stated that they had carried out socialization about the policy, one of them was a meeting or workshop. At the muni- cipal health office level they act as a companion team.

\section{b. Clarity}

In this study, all informants had the same understanding of the standard policy of pharmacy services at the health center and their relation to accreditation policies at the health center. They understand that accreditation is a process of assessment that what is done is in accordance with applicable rules. Whereas according to them, the standard of service is a guideline for them as pharmacy staff to work on how to serve patients. They also understand that the accreditation process and standard implementation are made with the aim of the process of improving the health center services.

The triangulation informant also explained that accreditation is a way to improve the quality of health center services and service standards for pharmaceutical guidelines for pharmacy staff in health center in conducting pharmaceutical services. Although not fully requested the points 
of accreditation have been fully stated in the standard guidelines and will soon be revised following the guidelines for accreditation of Puskesmas.

\section{c. Consistency}

Consistency in the implementation of policies on the implementation of pharmaceutical service standards in relation to the implementation of accreditation policies in Puskesmas in Bekasi City Health Center has not been seen significantly, because it has only been running for one year. The informants at the accredited health center explained their determination to maintain and improve the results of their performance on the accreditation results they had obtained.

\section{Resources}

a. Staff

Skilled human resource in adequate number is a necessary factor for implementing the policy (Situmorang, 2016). The community health centers have conducted training to increase human resource capacity with the assistance of the Provincial Health Office and the Ministry of Health.

The confirmation from the triangulation informant also stated that they also supported the readiness of human resources in the health center, although human resource factors were an obstacle in implementing this policy.

\section{b. Information}

Information relating to how to implement policies and data relating to policies that will be implemented (Anggara, 2014). Information on the implementation of the policy is clearly conveyed from the tiered center through the Bekasi City Health Office to policy implementers.

\section{c. Authority}

The policy authority to implement pharmaceutical service standards in health centers to policy implementers from the central as policy makers to the provincial level or regional government is carried out in stages. The Center conveyed the results of this policy to the provincial government, then the provincial government delivered it to the city or district government. The City or Regency Government is the one that delivers to the health center under it.

\section{d. Facility}

Physical facilities are important for the successful implementation of policies to facilitate the policy communication process.

\section{e. Disposition}

Disposition is the attitude and commitment of the implementer to the policy in order to achieve the expected policy outcomes (Anggara, 2014). The study informants were interested and commited in implementing the policy. Some obstacles existed. Some policy makers wished to raise their commitment.

\section{Structure of the Bureaucracy a. SOP}

One of the most basic structural aspects of an organization is its basic work procedure (Standard Operating Procedure $=$ SOP). By using an SOP, implementers can take advantage of the available time, and can uniform actions within the organization and broadly (Situmorang, 2016). In this study, all informants at the Puskesmas that had been accredited or not accredited had all had SOPs prepared 
in accordance with the situation and condition of the Puskesmas where they worked. The Bekasi City Health Office triangulation informant also stated that they were even in the process of making SOPs that would be applied in all Puskesmas in the Bekasi City area.

\section{b. Coordination between Exe- cuting Agencies}

Coordination between institutions or other relevant parties involved in this policy considered by the informants to be quite well. This goes well at the level of policy implementers and policy makers. Even among policy makers, they continue to coordinate with relevant parties for policy implementation.

\section{DISCUSSION
1. Communication}

The success of policy implementation is influenced by policy communication because unclear policy information causes policy implementers to tend not to adhere to policies (Weaver, 2009). Based on the results of the study, in general the communication policy on the implementation of pharmaceutical service standards has been perceived as it should. Pharmacy staff already have the knowledge and implement standard pharmacy service policies at the health center. This concerns the process of delivering or transmitting, the clarity and consistency of policy information submitted (Akib, 2010).

\section{Resources}

In terms of resources related to funding sources, staff, information, authority and facilities generally have been well fulfilled in Puskesmas in
Bekasi City. Fund support available in the budget in order to complement facilities and facilities for pharmaceutical service needs. Staff resources are seen from the number and competence, which generally have pharmacy staff and pharmacy technical staff. Thus, the health center has implemented pharmaceutical services such as providing drug information and counseling in line with policy. Quality human resources is by regularly participating in training held by the Bekasi City Health Office. Clarity of information on policies is well conveyed among existing resources. Support for the required facilities from related parties such as the head of the puskesmas and the authority possessed by pharmacy staff to implement the policy also been going well. Although there is no room for special counseling areas as in the research of Mehralian et al., (2014) that the absence of private space becomes an obstacle in the implementation of counseling (Mehralian, Rangchian, and Javadi, 2014).

\section{Disposition}

Disposition is the attitude of the executor or implementing commitment to the policy. Commitment or attitude of policy implementers who have strong desires and high commitment to be able to achieve expected policy goals (Anggara, 2014). In implementing attitudes or commitments in the health centers in the city of Bekasi have shown a high commitment in implementing the policy. This is indicate by reports of work reported regularly and commitments from not only pharmacy personnel, but also commitment from the head of the 
health center. In addition, the Bekasi City Health Office is also committed to placing pharmacists in each health center and training to improve resource skills. This is in line with research conducted in health center in Kubu Raya District that despite facing challenges, all respondents gave a positive response to the accreditation policy because it was suitable to be used as a work guide in the development of quality management systems and efforts to improve the quality of the health center services (Molyadi, 2017).

\section{Bureaucratic structure}

According to Edwards III in Anggara (2014), the bureaucratic structure is a working mechanism established to manage the implementation of a policy and emphasizes the need for a Standard Operating Procedure (SOP) that regulates the flow of work among the implementers. SOPs are prepared as guidelines so that policy implementers know what to do. At the health center in the city of Bekasi, they already have an SOP as a guide to work. In fact, according to the Head of the Pharmaceutical Section of the Bekasi City Health Office, it is in the process of drafting an SOP that will apply uniformly throughout the Bekasi City Health Center. In the Government Regulation Number 51 of 2009 it has also been stipulated that in carrying out pharmaceutical work, a pharmacist must establish standard operational procedures that are made in writing and continuously updated following the pharmaceutical service paradigm and in accordance with the development of science and technology.
The limitation in this study is that only 4 health centers used the purposive sampling method, namely two accredited health centers and two health centers that had not been accredited due to the limited time of the study. The implementation of standard pharmaceutical service policies at the health center is expected to improve the performance of the puskesmas. Although in the research conducted by Riyadi (2017), there was no relationship between the accreditation status of the health center and the level of patient satisfaction in the Bantul District health center, Yogyakarta (Riyadi, 2017).

The policy of the Minister of Health Regulation No. 74 of 2016 concerning Pharmaceutical Service Standards at the health center has been implemented well in health center in Bekasi City to support health center accreditation in 2018 seen from the aspects of communication, resources, disposition, and bureaucratic structure. Implementation of policies needs to be implemented consistently so that pharmaceutical services and achievement of accreditation can continue to run well as well as the existence of internal monitoring and evaluation.

\section{REFERENCE}

Akib H (2010). Implementasi Kebijakan: Apa, Mengapa, dan Bagaimana Haedar Akib. 1(1): 111.

Bappenas (2014). Peraturan Presiden Republik Indonesia Nomor 2 Tahun 2015 Tentang Rencana Pembangunan Jangka Menengah Tahun 2015-2019. doi: 10.1017/CBO9781107415324.004.

Direktorat Pelayanan Kefarmasian 
(2018). Laporan Kinerja Direktorat Pelayanan Kefarmasian Tahun 2017. doi: 10.1360/zd2013-43-6-1064.

Mehralian G, Rangchian M, Javadi AFP (2014). Investigation on Barriers to Pharmaceutical Care in Community Pharmacies: A Structural Equation Model', International journal of Clinical Pharmacy.

Grahmidri PR (2018). Standar Pelayanan Kefarmasian Di Puskesmas Kota Bekasi Tahun 2018.

Kemenkumham (2009). Undang-undang Nomor 36 Tentang Kesehatan. Beirut, Libanon.

Riley WJ, Bender K, Lownik E (2015).
Public Health Department Accreditation Implementation : Transforming Public Health Department Perormance. 102(2): 2008-2013. doi: 10.2105/AJPH.2011.300375.

Riyadi A (2017). Hubungan Status Akreditasi Puskesmas Dengan Tingkat Kepuasan Pasien Di Puskesmas Kabupaten Bantul. Sekolah Tinggi Ilmu Kesehatan Jenderal Ahmad Yani. Available at: http://www.albayan.ae.

Weaver RK (2009). Target Compliance : The Final Frontier of Policy Implementation Governance Studies. 